\title{
Evaluering for læring
}

\section{Bent B. Andresen}

Forskningsleder, ph.d.

Institut for Curriculumforskning

Danmarks Pædagogiske Universitet

bba@mail.dk

http://www.dpu.dk/om/bba

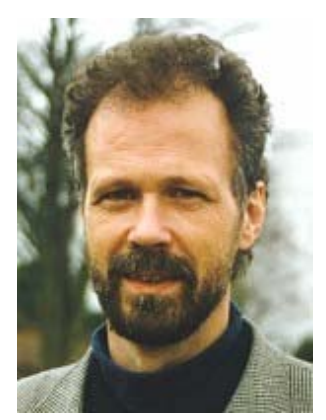

Forfatterens forskningsinteresser omfatter følgende tre hovedområder:

1) kompetenceudvikling under forskellige vilkår, herunder særligt IT som vilkår for læring

2) brugbarhed af IT i relation til læring og videndeling

3) forsknings- og evalueringsmetoder.

Han er forfatter til et dusin bøger og mange artikler om disse emner.

\section{Indledning}

Det er karakteristisk for design af blended e-læring, at opmærksomheden er rettet mod læringsaktiviteterne. Deltagerne lærer jo gennem det, de foretager sig - og kun gennem det.

Derfor er det vigtigt at evaluere disse aktiviteter. Resultater af evalueringer er grundlag dels for undervisningens planlægning, dels for vejledningens gennemførelse. Det er temaet i denne artikel.

\section{Hensigten med at evaluere}

Heidegger har analyseret menneskets brug af redskaber og skelner i den forbindelse mellem to perspektiver. En hammer bruges fx til at slå søm i med. Det sker fx for at hænge billeder op, hvilket er det egentlige formål. Tilsvarende anvendes mobilt og stationært IT-udstyr ved elæring til at lette adgangen til læringsressourcer og tjenester, udveksle meddelelser, præsentere deltagerprodukter og samarbejde. Det sker bl.a. for at skabe passende udfordringer for alle deltagere, øge deres læringsudbytte og udvikle tidssvarende arbejdsformer.

I den forbindelse er evaluering et redskab til at dokumentere deltagernes læreprocesser, hvilket bl.a. kan ske for at fremme deres udbytte heraf. Vi kan føre Heideggers skelnen et skridt videre, og overordnet skelne mellem to evalueringsformer. Den ene form, som kan betegnes evaluering for læering, er fremadrettet med fokus på deltagernes læring. Den foregår løbende for at skabe de bedst mulige rammer for denne læring, med alt hvad det indebærer at passende udfordringer, materialer og differentieret undervisning og vejledning.

I modsætning til fremadrettet evaluering, som er integreret i undervisningen, er den anden form bagudrettet og isoleret fra undervisningen. Denne form, som kan betegnes evaluering af læring, gennemføres ofte ved afslutningen af et læringsforløb for at opsummere deltagernes udbytte heraf og evt. også kontrollere og sortere deltagernes præstationer (bestået og ikkebestået), således som det kendes fra eksamener og skriftlige eller mundtlige evalueringer af forløbets værdi. 
Evaluering for læring kan være grundlag for tilrettelæggelse af læringsforløb. Nøgleordet er opfølgning. Uden opfølgning på evalueringerne er fremdriften begrænset, og omvendt kan sådanne opfølgninger medvirke til at øge kvaliteten af blended e-læring. Herved opstår spørgsmålet om, hvordan man bedst kan følge op på data fra en evaluering. Det er temaet i det følgende.

\section{Opfølgning på evaluering}

Systematisk opfølgning er i mange tilfælde en udfordring. Dahler-Larsen (2001) beskriver seks mysterier i den nuværende evalueringspraksis. Et mysterium er, hvordan det kan være, at man ofte ved, man skal evaluere, men ikke hvorfor og hvad evalueringen skal bruges til. Denne observation gør det relevant at ændre nogle grundlæggende antagelser om evaluering. Et ændret tankesæt kan fremme overvejelserne over, hvordan man bedst kan planlægge på grundlag af evalueringer og handle på resultaterne heraf.

En mulig rækkefølge kan fx være: 1) planlægning af opfølgning på evaluering og design af et e-læringsforløb, 2) gennemførelse af forløbet med integreret (løbende, intern) evaluering. I praksis er processen naturligvis ikke lineær, men en iterativ proces, hvor man vender tilbage til udgangspunktet og gør det til genstand for fornyet overvejelse i lyset af det, man hidtil har tænkt.

Nogle svar på spørgsmålet hvorfor evaluering er således:

- for at skabe passende udfordringer for deltagerne,

- for at afpasse vejledningen i forhold til deltagernes behov,

- for at dokumentere undervisningens og læringens kvalitet,

- for at sikre, at den lever op til de opstillede mål i bekendtgørelser, studieordninger o.l.

Det fremgår af disse svar, at evalueringer ikke er et mål i sig selv - hvilket jo er deltagernes læring - men et middel og grundlag for planlægning af læringsforløb. Det er den omvendte verden i forhold til at planlægge uden nøje kendskab til den enkelte deltagers potentialer og udviklingsmuligheder.

Det falder uden for rammerne af denne artikel at behandle design af blended e-læring nærmere. I stedet henvises til Andresen 2003. Desuden skal nævnes, at det er vigtigt at designet på et tidligt tidspunkt inddrager mulighederne for at følge op på evalueringer, som sker for at fremme deltagernes læring. Beskrivelser af den bebudede opfølgning (hvem gør hvad hvornår?) fungerer derpå som beslutningsgrundlag ved valg af de evalueringsmetoder, som skal anvendes.

Ved begrebet metoder forstås i denne sammenhæng fremgangsmåder og teknikker til indsamling og analyse af evalueringsdata. Ved at afpasse metoderne til den bebudede opfølgning undgås, at data fra evalueringer ligger ubrugt hen. Princippet er, at den bebudede systematiske opfølgning fastlægger evalueringens emner og metoder. På denne måde kan evalueringsdata være et grundlag for opfølgning på områder som deltagernes forudsætninger og forventninger, men også kvaliteten af deres læring, kommunikation og samarbejde.

At evaluere kan defineres som det at sætte værdi på deltagernes læring i forhold til givne mål med henblik på opfølgning. Evaluering for læring rejser derfor spørgsmålet om, hvordan man kan tilvejebringe målestokke for deltagernes kompetenceudvikling. Dette spørgsmål behandles kort i de følgende. 


\section{Målestokke for evaluering}

For at deltagerne kan vide, hvad de går ind til, når de påbegynder et læringsforløb, må de vide, hvilke kompetencer (almene, personlige, sociale og/eller faglige), det er hensigten, at de udvikler.

Vi kan skelne mellem nominelle og operationelle læringsmål. Nominelle mål er typisk hensigtserklæringer, som er så generelle, at det er vanskeligt at vurdere, hvornår deltagerne når disse mål. I det amerikanske uddannelsessystem er et sådant generelt mål fx problem solving. Hvis denne kompetence ikke bliver defineret nærmere, rejser det et spørgsmål om, hvad der kræves, for at en deltager har udviklet en sådan evne.

Operationelle mål fastlægges med henvisning til handlinger, som deltagerne er i stand til at udføre, fx at formulere en problemstilling eller gennemføre en empirisk undersøgelse. Sådanne mål gør det lettere at vurdere, hvornår deltagerne ankommer med succes. Særligt er de egnet som grundlag for selvevalueringer og refleksioner over egen læring.

På uddannelsesinstitutionerne kan man styrke den interne videndeling om operationelle mål. Man kan fx tilvejebringe et katalog til inspiration ved planlægning og evaluering af læringsaktiviteter. Hvis der ikke findes operationelle mål for deltagernes læring, bliver det en opgave for underviserne at formulere dem inden for rammerne af bekendtgørelser, studieordning o.l.

Bagefter er det en fordel for undervisere og vejledere, at de kan bygge på disse mål ved deres planlægning. Desuden er det en fordel for dialogen mellem undervisere og vejledere, at forventningerne er kendte. En tredje fordel er som nævnt, at deltagerne ved, hvad de går ind til.

Deltagerne benytter læringsmålene, når de selv evaluerer deres indsats og udbytte, ligesom de kan fastsætte individuelle forventninger og mål med udgangspunkt i de mål, som er fælles for et hold eller et forløb. Individuelle arbejds- og resultatmål, som noteres i deltagernes logbøger, kan fx være udgangspunkt for refleksioner over egen læring og selvevaluering heraf.

\section{Evalueringsemner}

Det, der ikke bliver evalueret, bliver overset. Hvis man konsekvent undlader at evaluere på et område, vil det efterhånden blive opfattet som underordnet eller ligegyldigt. Derfor er det væsentligt at dække alle de områder, hvor man ønsker at udvikle og sikre kvaliteten af en pædagogisk praksis.

Et fag omfatter typisk nogle begreber, emner og arbejdsmetoder. En evaluering bør i princippet omfatte alle tre områder. Afhængig af uddannelsesform kan den ligeledes omfatte forskellige almene, personlige og sociale kompetencer. Et eksempel på et bredt spektrum af evalueringsemner er:

- begrebsdannelse og emnekendskab,

- arbejdsformer og læringsstil,

- selvværd og motivation,

- kommunikation og samarbejde,

- literacy-kompetencer.

Evalueringen præges af metoden, som benyttes ved indsamling af evalueringsdata. Vi kan skelne mellem uformelle evalueringer, som bl.a. foretages på grundlag af iagttagelser, samtaler og spørgerunder, og formelle evalueringer, som foretages ved brug af metoder som åbne opgaver, faglige test og deltagernes egenproduktioner.

Som oftest er det en fordel at kombinere forskellige metoder for at få et dækkende indtryk af deltagernes udvikling. Det er temaet i det følgende. 


\section{Evalueringsdata}

Indsamlingen af evalueringsdata er ingen umulig opgave. Udover at afklare hvilke emner der skal medtages, og hvilke metoder der skal anvendes, er det naturligvis nødvendigt at prioritere, at der er tilstrækkelig med ressourcer til at gennemføre evalueringen. Desuden kan man overveje, om brugen af IT kan medvirke til at gøre opgaven mere overkommelig. IT-baserede metoder kan i mange tilfælde komplettere andre metoder ved evaluering og gøre det lettere at følge deltagernes selvstændige arbejde. Undervejs afleverer de udkast til besvarelser. De modtager herefter kommentarer vedrørende styrkesider og forslag til punkter, de med fordel kan udbygge og revidere. Derpå arbejder de videre, idet de tager ved lære af de fremadrettede evalueringer.

Læringsformen er i så fald en kombination af proces- og forståelsesorienteret læring. Arbejds- og læreprocesserne tillægges i princippet lige så stor værdi som produkterne, for deltagerne lærer jo kun gennem det, de foretager sig. Ved at følge arbejdet tæt og kommentere løbende kan vejlederne relativt let evaluere processen, og deltagerne kan umiddelbart drage nytte af spørgsmål og kommentarer. Det er fx tilfældet, når deres indsats er koncentreret omkring en åben opgave, en case eller en problemstilling.

Det væsentligste ved forståelsesorienteret læring er ikke, at deltagerne reproducerer faglig viden, men at de udvikler forståelsesformer fra humaniora, samfundsvidenskab og naturfag (Gardner 2000). Evalueringen tager i dette tilfælde udgangspunkt i deltagernes fremvisning af denne forståelse. Det kan fx ske gennem mundtlige præsentationer, skærmpræsentationer og skriftlige udtryk. Ved disse lejligheder får vejlederne og andre deltagere et indblik i deltagernes læreprocesser, som er grundlag for evalueringen.

Evalueringsopgaven kan blive mere overkommelig ved inddragelse af en digital platform. Det er for det meste en fordel for alle parter, at det hele er samlet ét sted på en læringsplatform (LMS e.l.). Her kan deltagerne gemme deres udkast, færdige arbejder i en portfolio, få differentieret respons samt hente informationer om undervisningen, materialer og opgaver.

Begrebet portfolioevaluering betegner en fremadrettet evaluering, som er integreret i undervisningen, og hvor evalueringsdata, som navnet siger, opbevares i en portfolio sammen med deltagernes refleksioner over deres læring. Der er normalt én portfolio for hver deltager, som de benytter til at samle og gemme, reflektere over, vælge ud og præsentere deres arbejder.

Ved portfolioevaluering er det ofte en udfordring at beslutte:

- hvad der skal gemmes,

- hvor det skal gemmes,

- hvad der skal udvælges,

- hvordan det skal anvendes?

For at gøre beslutningerne lettere kan undervisere og deltagerne fx drøfte kriterier for udvælgelse, konkretisere forventninger til fremlæggelser samt operationalisere de givne læringsmål.

I praksis er det en udfordring for undervisere, at de har to principielt forskellige roller under forløbet. På den ene side påtager de sig opgaven med at vejlede og støtte deltagerne i arbejdet med indholdet i deres portfolio. På den anden side har de rollen som dem, der til sidst skal vurdere og bedømme indholdet heraf.

Udover på udkast, produkter og fremlæggelser, kan sidstnævnte vurdering og bedømmelse baseres på deltagernes refleksioner. Refleksionerne over deltagernes arbejds- og læreproces kan være mundtlige eller skriftlige (logbog). Hvis deltagerne ikke reflekterer over deres erfaringer under processen, er der ikke tale om en portfolioevaluering (Ellmin 2000). 
Udover deltagerinvolverende og målbaserede evalueringsformer repræsenterer de såkaldte virkningsevalueringer en tredje evalueringsmodel. Denne model er særlig relevant i forbindelse med opfølgning. Det er temaet i det følgende.

\section{Virkningsevalueringer}

Årsag og virkning giver associationer til en deterministisk forståelse af læring, som der ikke er belæg for. Når virkningen er kendt, er det sjældent muligt at udpege bestemte årsager. Derimod har man viden om, under hvilke omstændigheder den bebudede virkning kan indtræffe, hvilket kan være til stor nytte ved udvikling af disse omstændigheder.

Der er bl.a. gennemført virkningsevalueringer i forbindelse med de former for blended elæring, som har fleste deltagere i Danmark. Det er det pædagogiske IT-kørekort for lærere i grundskolen og den obligatoriske sikkerhedsuddannelse (Andresen \& Knudsen 2005). Evalueringsmodellen har i begge tilfælde medtænkt den oplevede nytteværdi af efteruddannelsen, dvs. i hvilket omfang deltagerne vurderer, at den ruster dem til deres praksis.

Deltagerne er blevet spurgt om dette i løbet af det første år efter, at de har afsluttet efteruddannelsen. Ved den teambaserede IT-pædagogiske efteruddannelse var evalueringsemnerne bl.a.:

- $\quad$ lærernes brug af IT som personligt redskab til forberedelse og materialeproduktion og som led i undervisningen,

- brugen af IT til dialog og samarbejde med kolleger, ledelse og forældre,

- involvering i udmøntningen af IT-strategier og -handleplaner samt gennemførelse af udviklingsprojekter med IT.

Ved arbejdsmiljøuddannelsen omfattede evalueringsemnerne bl.a. følgende dimensioner:

- medvirken til kontrol af arbejdsmiljøet,

- medvirken til at påvirke lederes og medarbejderes holdning til arbejdsmiljøet,

- søge og anvende informationer om arbejdsmiljøet.

Evaluering af den oplevede nytteværdi af disse aktiviteter skaber viden om, hvorvidt uddannelsen gør en forskel på længere sigt. Denne metode er derfor egnet til at skaffe en mere komplet viden om de evaluerede forløb.

Ved mål- og deltagerbaserede evalueringer er evalueringsresultaterne i nogle tilfælde omvendt proportionale med kravene. Såfremt et e-læringsforløb er relativt let at gennemføre, vil deltagernes evaluering typisk være positiv uden tanke for, at udfordringerne måske burde have været større for at forberede dem bedre til deres professionelle praksis.

Det kan derimod afdækkes gennem en virkningsevaluering. Viden om den oplevede nytteværdi af et læringsforløb er af den grund et væsentligt grundlag for at vurdere læringsforløbets betydning og sikre kvaliteten heraf.

\section{Afrunding}

Ved blended e-læring begynder planlægningen ideelt set ikke med, at underviseren overvejer sine oplæg og materialer, men med at overveje deltagernes aktiviteter. Det indledende fokus skifter fra informationsdelen til aktivitetsdelen i læringsforløbet. Tilsvarende sker der et skift i opfattelsen af, hvordan man kan vurdere forløbets værdi. Der er i den forbindelse ingen erstatning for viden, som skabes på grundlag af analyser af evalueringsdata.

I artiklen skelnes mellem evaluering for læring og evaluering af læring. Som navnet siger, er hensigten med førstnævnte evalueringsform at fremme deltagernes læring. Det er en løbende, 
intern evaluering, som bl.a. har til formål at skabe de bedst mulige vilkår for denne læring, herunder passende udfordringer, materialer og differentieret undervisning og vejledning.

Dette til forskel fra sidstnævnte evaluering, som er bagudrettet og typisk gennemføres ved afslutningen af læringsforløb på grundlag af fx eksamen eller en samtale bordet rundt om forløbets værdi (det samlede billede).

Opfølgning er helt centralt ved gennemførelse af evaluering for læring. Den bebudede opfølgning afgør, hvilke evalueringsdata, der er behov for at indsamle for at udvikle vilkårene for deltagernes læring.

Det omfatter typisk data om deltagernes forudsætninger og forventninger, men også om progressionen i deres læring, kommunikation og samarbejde, som indsamles og analyseres og danner grundlag for tilrettelæggelse af læringsforløb. Princippet er, at design af e-læring bygger på analyser af evalueringsdata, som kan omfatte både proces og virkning på kort og mellemlang sigt.

\section{Litteratur}

Andresen, Bent B. "Hvorfor e-pædagogik?". Tidsskrift for Universiteternes Efter- og Videreuddannelse, nr. 1, 2003. http://www.unev.dk/default.aspx?page $=110$

Andresen, Bent B. \& Brian Knudsen, Best practice in professional development: How to improve the quality of real-life e-learning? Paper at WCCE 2005. Cape Town: University of Stellenbosh, 2005.

Ellmin, Roger. Portfoliomodellen. En måde at læere og teenke på. København: Gyldendal Uddannelse, 2000.

Dahler-Larsen, Peter. Den rituelle refleksion - om evaluering i organisationer. Odense: Odense Universitetsforlag, 2001.

Gardner, Howard. Disciplin og dannelse - betydningen af det sande, det smukke og det gode. København: Gyldendal Uddannelse, 2000. 